Z. klin. Chem. u. klin. Biochem.

8. Jg., S. 398-402, Juli 1970

\title{
A New Method for the Determination of Serum Nucleotidase
}

\author{
$I V$. Evaluation of the conditions for assays using adenosine deaminase ${ }^{1}$ ) \\ By J.-P. Persijn, W. van Der SitK, C. J. Timmer and C. M. Rejuntjes \\ From the Department of Clinical Chemistry (Head dr. J.-P. Persijn), Netherlands Cancer Institute, Amsterdam \\ and the Department of Clinical Chemistry (Head drs. W. van der Slik), State University Hospital, Leiden, Holland
}

(Eingegangen am 27. Februar 1970)

Several conditions affecting the assay of serum $5^{\prime}$-nucleotidase ${ }^{2}$ ) using the Berthelot reaction were examined. The results are used in an evaluation of the methods for $5^{\prime}$-nucleotidase using the enzyme adenosine deaminase ${ }^{2}$ ).

Verschiedene Bedingungen, die die Bestimmung der Serum-5'-Nucleotidase ${ }^{2}$ ) mit der Berthelot-Reaktion beeinflussen, wurden untersucht. Die Ergebnisse werden für eine Bewertung der Methoden für $5^{\prime}$-Nucleotidase, die mit Adenosindesaminase ${ }^{2}$ ) arbeiten, verwendet.

In 1968 we introduced a new method for the assay of serum-5'-nucleotidase in which the adenosine liberated from the substrate adenosine-5-monophosphate (AMP) was determined using the enzyme adenosine-deaminase.

$$
\dot{A M P} \stackrel{5 \text { 'nucleotidase }}{\longrightarrow} \text { adenosine }+\mathrm{P}_{\mathrm{i}}
$$

(2) adenosine $+\mathrm{H}_{2} \mathrm{O} \stackrel{\text { adenosine deaminase }}{\longrightarrow}$ inosine $+\mathrm{NH}_{3}$

Reaction (1) caused by serum-5'-nucleotidase is followed immediately by reaction (2) since adenosine deaminase is present in the assay mixture during incubation. The enzymatically liberated ammonia, which is proportional to the $5^{\prime}$-nucleotidase activity, is measured by the indophenol reaction (BERTHELOT)

For the experimental details the reader should consult references 1.c. (1), (2) and (3). In brief, the assay is started by the addition of $100 \mu l$ serum to $1.0 \mathrm{ml}$ incubation medium (veronal buffer $\mathrm{pH} 7.5$ at $21^{\circ} \mathrm{C}$ ) containing $5 \mu \mathrm{Mol} \mathrm{AMP}, 25 \mu \mathrm{Mol} \mathrm{MgSO}_{4}$ and $500 \mathrm{mU}$ adenosine deaminase at $37^{\circ} \mathrm{C}$. To inhibit non-specific bone-phosphatase $8 \mu \mathrm{Mol}$ phenylphosphate must also be present. The $\mathrm{pH}$ of the final mixture is $7.33-7.41$ at $37^{\circ} \mathrm{C}$; after 1 hour incubation it rises to $7.43-7.51$ at $37^{\circ} \mathrm{C}$. For the blank the AMP is omitted. After incubation for 60 or 75 min the phenol and hypochlorite reagent can be added. In the phenol reagent EDTA $(5.3 \mu \mathrm{Mol} / \mathrm{m} l)$ is present to prevent precipitation of $\mathrm{Mg}$ salts which would interfere in the measurement of the colour. The final indophenol blue colour is read at $625 \mathrm{~nm}$ after a further $30 \mathrm{~min}$ incubation. In references 1. c. (1), (2) and (3) evidence has been given of the sensitivity of this method and of the fact that pathological sera do not interfere with the Berthelot-reaction. In reference $1 . c$. (4) additional information is given about the type of buffer, effect of incubation time, and

1) Part III see 1.c. (3).

2) Enzymes: 5'-Nucleotidase (EC 3.1.3.5), Adenosine deaminase (EC 3.5.4.4), Alkaline Phosphatase (EC 3.1.3.1), AMP-deaminase (EC 3.5.4.6). precision of the method as shown by data derived from routine control, etc.

However a number of questions have arisen concerning

a) substrate and serum-protein concentrations, presumably in reference to those used in kinetic assays for 5 '-nucleotidase based on the decrease of absorbance at $265 \mathrm{~nm}$ as a consequence of the conversion of AMP to inosine (reaction (1) and (2)).

b) the influence of EDTA on the final extinction of the indophenol blue reaction.

This paper provides a more detailed presentation of the answers to these questions. Some results will be discussed in connection with the aspects of the kinetic method for 5'-nucleotidase as mentioned sub a).

\section{Materials und Methods}

AMP and adenosine deaminase (stabilised with 50\% glycerol) were obtained from Boebringer Mannheim. The other chemicals were obtained from BDH in England.

The 5'-nucleotidase activity was measured according to references 1. c. (1) and (2), and the variations are described in the text. Total protein content was measured with the biuret reaction; the conversion factor used was derived from Kjehldahl estimations in a standard serum. The measurement of optical density in the ultraviolet range was performed with a Zeiss PMQ II spectrophotometer.

\section{Results}

In the previous papers $(1,4)$ evidence has been given of the direct relationship between optical density at $625 \mathrm{~nm}$ and the amount of enzyme in the range 0 to $100 \mu \mathrm{l}$ serum. Figure 1 shows the extent to which the final indophenol-blue colour as a measure of 5 '-nucleotidase activity is proportional to the quantity of serum added. The two curves refer to serum pools of different total protein content and different $5^{\prime}$-nucleotidase activity.

As can be seen from figure 1 a deviation from the linear relationship between optical density and amount of

Z. klin. Chem. u. klin. Biochem. / 8. Jahrg. 1970/ Heft 4 
serum becomes apparent if the quantity of serum is about $150 \mu l$. The deviation from linearity is small; at $200 \mu \mathrm{l}$ it amounts to only about $9 \%$.

The effect of the EDTA present in the phenol reagent is shown in figure 2 . In the range $0-3 \mu \mathrm{Mol} / \mathrm{m} l$ some

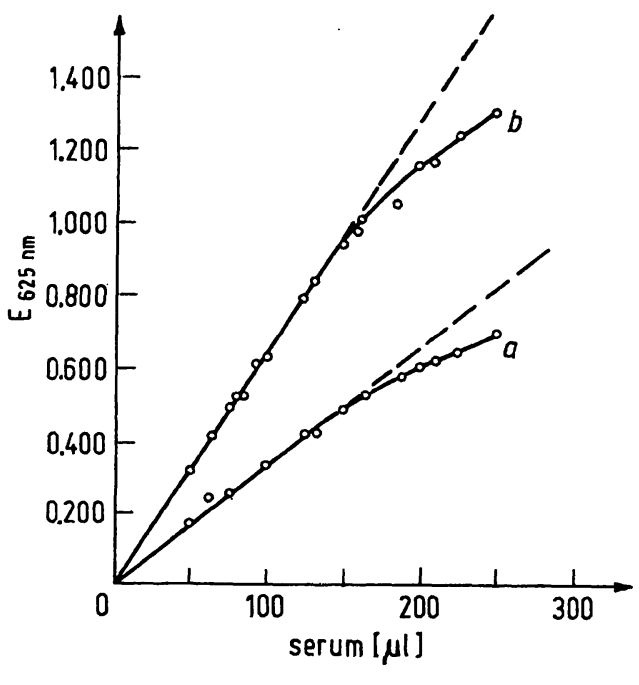

Fig. 1

Relationship between volume of serum and extinction of Berthelot reaction produced after incubation

a) pooled serum with protein content of $6.6 \mathrm{~g} / 100 \mathrm{ml}$, and 5'-nucleotidase activity of $30.4 \mathrm{mU} / \mathrm{ml}$

b) pooled serum with protein content of $7.8 \mathrm{~g} / 100 \mathrm{ml}$, and 5'-nucleotidase activity of $58.9 \mathrm{mU} / \mathrm{ml}$

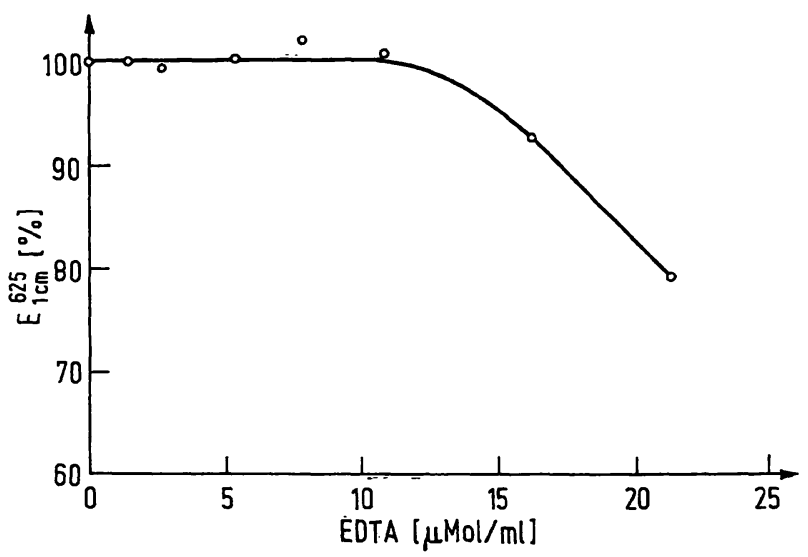

Fig. 2

Effect of the concentration of EDTA in the phenol reagent on the extinction of the Berthelot reaction as performed in the 5'-nucleotidase assay according to PERSIjN and VAN DER SLIK

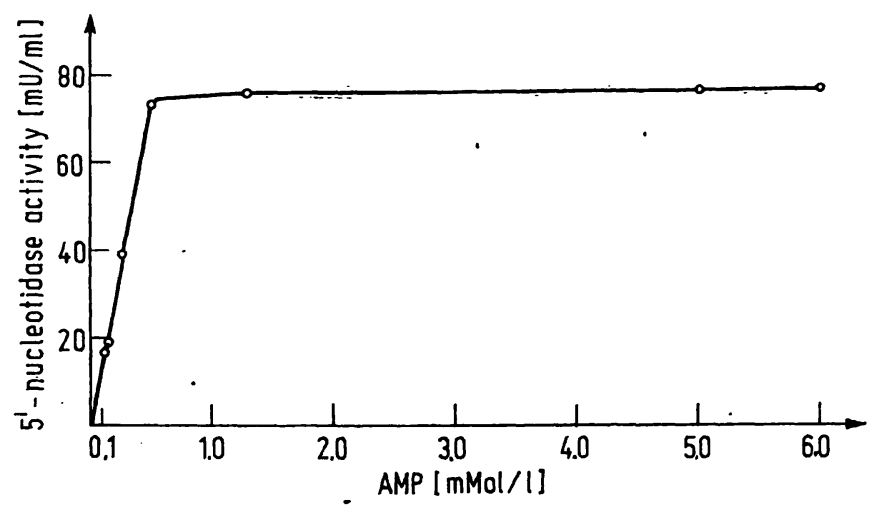

Fig. 3

Activity as function of substrate concentration precipitate was formed which was centrifuged off. In separate experiments it was confirmed that the precipitate did not adsorb colour to any significant extent.

As can be seen from figure 2 on increasing the concentration of EDTA in the phenol reagent beyond $10 \mu \mathrm{Mol} /$ $\mathrm{m} l$ the extinction of the final mixture is progressively diminished. The actual concentration of EDTA in our method is $5.3 \mu \mathrm{Mol} / \mathrm{ml}$, thus EDTA does not affect the sensitivity of the assay for 5'-nucleotidase under our conditions.

Figure 3 illustrates the measured 5'-nucleotidase activity with substrate concentration up to $6 \mathrm{mMol} / \mathrm{l}$. In fact activity remains constant at concentrations up to $10 \mathrm{mMol} / l$ (not tested further). The experiment was performed with a pooled scrum showing a relatively low alkaline phosphatase level $(360 \mathrm{mU} / \mathrm{ml}$, normal range till $116 \mathrm{mU} / \mathrm{m} /$ ).

Attention was paid to $5^{\prime}$-nucleotidase activity at AMP concentrations of 0.100 and $0.125 \mathrm{mMol} / l$ in order to obtain data to compare with the statement of BECKMANN and coworkers (5) and GoldBerg (6) that substrate inhibition takes place at concentrations above 0.120 $\mathrm{mMol} / l$. This was not found to be the case in our method, in which a concentration of $5.0 \mathrm{mMol} / /$ incubation medium was chosen, according to SCHWARTZ and BODANSKY (7).

\section{Discussion}

In figures 1, 2 and 3 evidence is provided to confirm earlier (unpublished) findings that the concentration of substrate or serum or EDTA in the colour reagent in our standard procedure as described in reference $1 . \mathrm{c}$. (1) is satisfactory. The serum protein content in cases of liver diseases seldom exceeds $8 \mathrm{~g} / 100 \mathrm{ml}$. In view of this, the application of $125 \mu l$ serum cannot be expected to cause interference from serum proteins. Generally speaking serum proteins will not affect our method for $5^{\prime}$-nucleotidase provided that the amount of protein does not exceed $10 \mathrm{~g} / 100 \mathrm{ml}$.

With regard to the substrate concentration a remarkable discrepancy in AMP concentration can be found between colorimetric and kinetic assays for 5'-nucleotidase.

Table 1 summarizes the AMP concentrations used by different authors in the incubation media for serum 5'-nucleotidase. The colorimetric methods for 5'-nucleo-

Tab. 1

AMP concentrations, used for the determination of 5 '-nucleotidase activity

\begin{tabular}{lccc}
\hline \multicolumn{1}{c}{ authors } & reference & method & $\begin{array}{c}\text { AMP concentration } \\
(\mathrm{mMol} / \mathrm{l})\end{array}$ \\
\hline SONG and BODANSKY & $(8)$ & PO. & 5.0 \\
BELFIELD and GOLDBERG & $(9)$ & U.V. & 0.1 \\
BECKMANN and COWOrkers & $(5)$ & U.V. & 0.1 \\
SCHWARTZ and BODANSKY & $(7)$ & PO. & 5.0 \\
DIXON and PURDOM & $(10)$ & PO. & 2.5 \\
CAMPBELL & $(11)$ & PO. & 1.0 \\
BELFIELD and GOLDBERG & $(12)$ & PO. & 1.0 \\
\hline
\end{tabular}


tidase based on the determination of inorganic $\mathrm{PO}_{4}$ released from AMP are designated by " $\mathrm{PO}_{4}$ ", the kinetic methods based on measurements at $265 \mathrm{~nm}$ by the symbol U.V. It is interesting to note that the authors 1.c. (12) and (9) raise the AMP concentration while changing from the kinetic to a colorimetric method. The answer to the question why in the kinetic method appreciably lower concentrations are used seems to be that AMP contributes to a relatively high extent to the final optical density of the assay mixture. This is illustrated in Table 2. In this connection it should be pointed

Tab. 2

Optical density at $265 \mathrm{~nm}$ of AMP solutions in Tris-buffer at $\mathrm{pH} 7.5$

\begin{tabular}{cc}
\hline $\begin{array}{c}\text { concentration } \\
(\mathrm{mMol} / l) .\end{array}$ & $\begin{array}{c}\mathrm{O} . \mathrm{D} . \\
\text { (at } 265 \mathrm{~nm})\end{array}$ \\
\hline 5.0 & $\infty$ \\
1.0 & $\infty$ \\
0.12 & 1.65 \\
0.10 & 1.33 \\
\hline
\end{tabular}

out that serum can contribute considerably to the final O.D. of the assay mixture; in the medium of BECKMANN and coworkers this contribution to O.D. may be 1.3 to 2.0. In view of these facts it would probably be difficult to find the optimal substrate concentrations for the kinetic method for serum 5'-nucleotidase. The development of kinetic methods for 5 '-nucleotidase dates back to 1947, in which year KALCKAR introduced a method for the determination of adenosine (13). $\mathrm{He}$ found that the addition of adenosine deaminase to a solution of adenosine resulted in a rapid decrease of O.D. at $265 \mathrm{~nm}$ to approximately 40 per cent. His quantitative method for adenosine is based on this change. The suggestion of KaICKAR (14) to use such a reaction for the assay of 5 -nucleotidase was followed up by SEgAL and BRENNER (15) in their study of 5'-nucleotidase in rat liver microsomes. After a certain incubation period the enzymatic reaction was terminated and the adenosine released was determined according to KAICKAR.

In 1969 two detailed methods for the assay of $5^{\prime}$-nucleotidase in serum involving measurements at $265 \mathrm{~nm}$ were presented by LEYBOLD and coworkers (16) and BELFIELD and GoldBerg (17). The principles of the two methods were essentially the same, except for the addition of glycerophosphate in the latter, which is not a critical point in the present discussion. A salient point of difference with the SEgAL and BRENNER assay is that in the two former methods for serum $5^{\prime}$-nucleotidase the rate of decrease in O.D. at $265 \mathrm{~nm}$ is measured during the incubation period itself. The change of O.D. in kinetic methods is the results of the consecutive reactions (1) and (2):

(3) $\mathrm{AMP}+\mathrm{H}_{2} \mathrm{O} \longrightarrow$ inosine $+\mathrm{PO}_{4}+\mathrm{NH}_{3}$

and the decrease in O.D. following the conversion of AMP to inosine is a measure of the $5^{\prime}$-nucleotidase activity involved. The measurement of reaction (3) is made possible by the presence of adenosine deaminase in the incubation mixture and the fact that the spectral difference between AMP and inosine is similar to that between adenosine and inosine.

For the present discussion both the Segal-Brenner method and the kinetic method will be referred to as the u.v. method.

In this discussion we propose to consider two points:

a) the effect of the contamination of adenosine deaminase with AMP-deaminase in the u.v. method and our method using the Berthelot reaction.

b) the sensitivity of the u.v. method and our method for $5^{\prime}$-nucleotidase.

In an assay for 5'-nucleotidase using adenosine deaminase a second reaction can take place as a consequence of the contamination of.adenosine deaminase with AMP-deaminase:

$$
\mathrm{AMP} \longrightarrow \mathrm{IMP}+\mathrm{NH}_{3}
$$

This type of reaction is accompanied by a change in O.D. at $265 \mathrm{~nm}$ which is greater than in the case of reaction (3). The presence of AMP-deaminase will therefore interfere in both the u.v. method and our method. The extent to which in such a case the accuracy of the assay for 5'-nucleotidase activity will be diminished depends of course on the ratio of serum to adenosine deaminase present, but will be less in the Sègall-Brenner method. The conversion of adenosine in the latter by adenosine deaminase added in excess after the incubation takes place in a very short time (a few minutes) - therefore with a relatively long incubation time for 5 '-nucleotidase assay, AMP-deaminase present as contamination will presumably contribute to the overall change in O.D. only to a very minor extent - unlike the kinetic method and our method where the 5 '-nucleotidase and AMP-deaminase work simultaneously on their substrates. At low activity of $5^{\prime}$-nucleotidase the effect of AMP-deaminase can even prevail in the measured 5'-nucleotidase activity. This has not been taken into account by the authors 1. c. (16) and (17).

The following calculation is intended to show the importance of including corrections for AMP-deaminase activity in the results of kinetic measurements. It should be emphasized that the actual dependence on substrate concentration for AMP-deaminase has not been considered. The interpretation of the calculations should be accepted with some reserve. Several commercial batches of adenosine deaminase delivered in 1968 were found to be contaminated with AMP-deaminase. In the absence of serum after $60 \mathrm{~min}$ incubation time the O.D. at $625 \mathrm{~nm}$ in our method for $5^{\prime}$-nucleotidase was frequently found in the range $0.060-0.090$, the highest value being 0.230 ( $60 \mathrm{~min}$ incubation time). These values were not due to contaminations of AMP with adenosine. Such values were subtracted from total extinction in the presence of the serum tested to obtain real serum 5 '-nucleotidase levels.

The calculation of the interfering AMP-deaminase activity is facilitated by the fact that both 5 -nucleotidase and 


\title{
BULLETIN \\ DE LA \\ SOCIÉTÉ DE CHIMIE BIOLOGIQUE
}

\author{
(„Berichte der Gesellschaft für biologische Chemiec)' \\ Unter Mitwirkung des \\ „CENTRE NATIONAL DE LA RECHERCHE SCIENTIFIQUE“ \\ (National-Centrum für wissenschaftliche Forschung) veröffentlicht
}

J.-P. EBEL

Secrétaire Général

(Relations

extérieures)
Secrétaire Général

\section{F. PERCHERON}

Rédacteur en Chef Adjoint
R. PERLES

Y. RAOUL

Rédacteur en Chef

Sekretariat und Redaktion: 4 , avenue de l'Observatoire, Paris (6e)

Herausgeber: MASson et $\mathrm{CrE}, 120$, Boulevard Saint-Germain, Paris (6e)

Der „Bulletin DE LA Société de Chimie Biologique“ veröffentlicht jährlich 11 Hefte; diese enthalten die Arbeiten der französischen Biochemiker, welche der „SocIÉTÉ DE CHIMIEE BrologrQUE“ (Gesellschaft für biologische Chemie) angehören.

Abonnementspreis 1969:

Frankreich und „Franc-Zone“ . . 150 ffrcs

Belgien . . . . . . . . . 1684 bfres

Andere Länder . . . . . . . 165 ffrcs

\section{ACTA BIOCHIMICA ET BIOPHYSICA ACADEMIAE SCIENTIARUM HUNGARICAE}

Zeitschrift der Ungarischen Akademie der Wissenschaften

G. Cseh: Nucleotide Antagonism in the Hormone-sensitive Lypolysis of Fat Tissue

Gy. Bot, Edit F. Korács, Edit N. Pólyik: The Influence of Allosteric Effectors on the Conversion of Phosphorylase-b

F. Hajós, S. Kerpel-Fronius, Eva Schay: Electron Microscopic Demonstration of Differences between Succinic Dehydrogenase Activities of Brain Mitochondria in Homogenates and Mitochondrial Fractions

I. Alkonyi, E. Pálfi, D. Szabó: ATP-Dependent Enzymic Splitting of Mesitene Lactone and Triacetic Acid Lactone

I. Mile, V. Csányi, Ilona Ferencz: Reversible Change in Iodine Sensitivity of Penicellinase by Alkali Treatment

J. Hajdu, V. Csányi: The Influence of Concentrated Electrolytes on the Constitutive Penicellinase Synthesis of B-cereus (Short Communication)

M. Bálint, A. Schaefer, N. A. Biró: The Subunit Structure of Light-Meromyosin (Short Communication)

Susan Libor, P. Elödi: Selective Reaction of Tyrosyl Side Chains With Iodine in Glycetaldehyde-3-phosphate Dehydrogenase. III. Specificity of the Reaction in Urea. Determination of Reacting Histidine and Tryptophan (Short Communication)

L. Polgár: Transformation of a Serine Protease of Aspergillus oryzae into a Thiol Enzyme (Preliminary Communication).

E. Ernst: Bound Water in Physics and Biology

A. Pellionisz: Computer Simulation of the Pattern Transfer of Large Cerebellar Neuronal Fields

F. Aradi, Z. Futó: Quantitative Researches into the Volume Decrease of the Muscle, I

F. Aradi: Quantitative Researches into the Volume Decrease of the Muscle, II

G. Biró, K. Gábor, J. Örkényi:Frequent Excitation of the Nerve and Muscle

B. Tankó, T. Karsay, F. Teichmann: Employment of Collagen for Constructing a Mechano-chemical Machine

I. Bojtor, K. Dósay: Investigation on a Method Measuring Low Energy X-ray Doses with Energy-dependent Film Dosemeter (Short Communication)

Gy. Koczkás, K.Dósay: Physical Condition and Dosimetry Problems of Experimental Irradiations in Radiobiology (Short Communication)

Book Review

ACTA BIOCHIMICA ET BIOPHYSICA erscheint vierteljährlich in Heften zu einem Band von etwa 400-500 Seiteri. Format: $17 \times 24 \mathrm{~cm}$. Abonnementspreis pro Band: \$16.00; DM 64,-

Vertrieb: KULTURA, Budapest 62 . Postfach 149; Auslieferung für das Gebiet der Deutschen Bundesłepublik:

KUNST UND WISSEN, Erich Bieber, Stuttgart S, Wilhelmstraße

AKADÉMIAI KIADO, Verlag der Ungarischen Akademie der Wissenschaften, Budapest 502. Postfach 24 
AMP-deaminase are measured with the same conversion factor. If we take as an example the batch of adenosine deaminase showing in our method a false 5 '-nucleotidase activity as expressed in O.D. at $625 \mathrm{~nm}$ of 0.060 the amount of AMP-deaminase present amounts to:

$$
\frac{0.060}{0.680} \times \frac{0.375}{60} \times 10^{3}=0.55 \mathrm{mU} \text {. }
$$

where $0.060=$ extinction in absence of serum against blank at $625 \mathrm{~nm}$.

$0.680=$ extinction standard adenosine at $625 \mathrm{~nm}$.

0.375 = amount of adenosine standard $(\mu \mathrm{Mol})$ in test mixture.

$60=$ to express activity per minute.

$10^{3}=$ to convert to $\mathrm{mU}$.

When $500 \mathrm{mU}$ adenosine deaminase are present the contamination is about $0.1 \%$. This means that if in our method a sample with a real $5^{\prime}$-nucleotidase activity of $10 \mathrm{mU} / \mathrm{ml}$ is tested the test mixture will contain $1.0 \mathrm{mU}$ 5 -nucleotidase activity and $0.55 \mathrm{mU}$ AMP-deaminase activity.

Thus a $10 \mathrm{mU} / \mathrm{m} l$ sample will give a reading of $15.5 \mathrm{mU} /$ $\mathrm{ml}$, i. e. pathological.

In the kinetic method of 1. c. (17) the ratios of serum 5 -nucleotidase to adenosine deaminase present in the assay are extremely unfavourable as far as contamination with AMP-deaminase is concerned. Here $20 \mu \mathrm{l}$ serum are incubated in the presence of $1300 \mathrm{mU}$ adenosine deaminase. In the investigation of a serum with $10 \mathrm{mU} /$ $\mathrm{ml} 5^{\prime}$-nucleotidase activity the assay mixture contains $0.2 \mathrm{mU} 5^{\prime}$-nucleotidase and $1.4 \mathrm{mU}$ AMP-deaminase (approx. $0.1 \%$ contamination). In this case the serum 5 -nucleotidase activity will correspond to an O.D. at $265 \mathrm{~nm}$ amounting to:

$$
\frac{0.2 \times 20}{3.0} \times 8.0 \times 10^{6} \times 10^{-9}=0.011
$$

where $0.2=$ amount $5^{\prime}$-nucleotidase (mU) present in assay mixture.

$20=$ incubation time in minutes.

$3.0=$ total volume $(\mathrm{m} l)$ assay mixture.

$8.0 \times 10^{6}=$ molar extinction coefficient for reaction (3) according to 1. c. (17).

$10^{-9}=$ to convert to $\mathrm{nMol} / \mathrm{ml}$.

Since according to KaLCKAR (13) the molar extinction coefficient at $265 \mathrm{~nm}$ for reaction (4) is $8.75 \times 10^{6}$
$\mathrm{Mol}^{-1} \cdot \mathrm{cm}^{2}$, a similar calculation will show that $1.4 \mathrm{mU}$ AMP-deaminase will cause a change in O.D. of 0.082 . This change corresponds (according to 1 . c. (17)) to $0.082 \times$ $18,700 \times 0.05=76.9 \mathrm{mU} / \mathrm{ml}$ of falsely assayed $5^{\prime}$-nucleo. tidase activity. This example shows that with a contamination of only $0.1 \%$ the real $5^{\prime}$-nucleotidase activity $(10 \mathrm{mU} / \mathrm{ml})$ is only $12 \%$ of the totally measured activity $(86.9 \mathrm{mU} / \mathrm{ml})$. For the kinetic method according to BECKMANN and coworkers the ratios of serum and adenosine deaminase are more favorable resulting in a real participation of $5^{\prime}$-nucleotidase of $50 \%$.

Summarizing, it can be said that slight contamination of AMP-deaminase has little if any effect in the SegalBrenner method, but probably gives increasing interference in the Persijn-van der Slik method, and the kinetic methods according to BECKMANN and coworkers and Belfield and Goldberg in that order. Our method is placed first because it allows the use of a relatively large volume $(100 \mu l)$ of serum (Fig. 1). Corrections for AMP-deaminase as standard procedure are therefore indispensable. This is not a groundless demand since the authors of the kinetic methods presumably obtained their adenosine deaminase from the same commercial source as we did in 1968. It should be noted that at present Boehringer (Mannheim) or British Drug Houses (England) are marketing at our request adenosine deaminase preparations in which contaminations with AMP-deaminase are generally extremely low ( $\pm 0.02-0.04 \%$ ) corresponding to O.D. at $625 \mathrm{~nm}$ in the absence of serum of $0.010-0.020$.

To evaluate the sensitivity of the different methods the O.D. for a given $5^{\prime}$-nucleotidase activity $(10 \mathrm{mU} / \mathrm{ml})$ are tabulated (Tab. 3). For the calculations the data given by the authors mentioned are used, with the exception of the method of BECKMANN and coworkers.

These authors use a factor derived from reaction (2), but the actual concentration of adenosine during the kinetic assay approximates to zero, a point which has been overlooked in the calculation of the factor to convert results of the kinetic measurements to 5'-nucleotidase activities. In this case the factor of 1. c. (17) is applied. In the Segal-Brenner method we have replaced the volume of suspended microsomes by an equal volume of serum. This method seems to be the most sensitive with a final concentration of AMP of $1 \mathrm{mMol} / l$.

Other criteria for evaluation such as results of recovery experiments or data about reproducibility or accuracy

Tab. 3

Methods of assay of 5'-nucleotidase using adenosine deaminase

\begin{tabular}{|c|c|c|c|c|c|}
\hline method & ref. & $\begin{array}{l}\text { wavelength } \\
(\mathrm{nm})\end{array}$ & $\begin{array}{c}\text { incubation time (Min.) } \\
\text { at } 37^{\circ}\end{array}$ & $\begin{array}{c}\text { amount of serum } \\
(\mu l)\end{array}$ & O. D. \\
\hline 1. PERSIJN and VAN DER SLIK & (1), (3) & 625 & 60 & 100 & 0.108 \\
\hline 2. SEGAL and BRENNER ${ }^{2}$ ) & (13), (15) & 265 & 60 & 100 & 0.261 \\
\hline 3. BECKMANN and coworkers & (5), (16) & 265 & 4 & 100 & 0.011 \\
\hline 4. BELFIELD and GoLdBERG & (17) & 265 & 20 & 20 & 0.011 \\
\hline
\end{tabular}

Decrease in O. D. calculated from data in the references mentioned for a sample of $10 \mathrm{mU} / \mathrm{ml}$

2) modified 
in the $0-20 \mathrm{mU} / \mathrm{m} l$ range have not been presented for the kinetic methods but have been given for our method in 1. c. (1), (3) and (4). Nevertheless it seems justifiable to conclude that for a serum having a $5^{\prime}$-nucleotidase in the transition range of normal to elevated level the kinetic methods have only limited value in contrast with the method using the Berthelot reaction.
For biochemical studies the application of u.v. methods have the advantage of a greater choice of type of buffer while in our method there is only a limited choice (4). It is in the field of biochemistry that u.v. methods have value, especially the Segal-Brenner method with its minimal interference from slight contamination of adenosine deaminase with AMP-deaminase.

\section{References}

1. Persijn, J.-P., W. van der Slik, K. Kramer and C. A. de RuyTER, This journal 6, 441 (1968). - 2. Persijn, J.-P., W. VAN DER Surk, C. J. Timmer and A. W. M. Bon, This journal 7, 199 (1969). 3. Persijn, J.-P., W. van der Slik, and A. W. M. Bon, This journal 7, 493 (1969). - 4. VAN DER SLIK, W., J.-P. Persijn, E. Engelsman and A. Riethorst, Clin. Biochemistry 3, 59 (1970). - 5. BeckmanN, J., K. Leybold and L. WeIsBecker, This journal 7, 18 (1969). - 6. GolDBERG, D. M., private communication. - 7. Schwartz, M. K. and O. Bodansky, Cancer 18 , 886 (1965). - 8. Song, C. S. and O. Bodansky, Biochem. J., 101, 5c (1966). - 9. Belfield, A. and D. M. Goldberg, Nature
(London) 219, 73 (1968). - 10. Drxon, I. E. and M. Purdon, J. Clin. Path. (London) 7, 341 (1954). - 11. Campbeli, D. M., Biochem. J. 82, 34 P (1962). - 12. BeLFIELD, A. and D. M. GoldBERG, J. Clin. Path. (London) 22, 144 (1969). - 13. KaLCKAR H. M., J. biol. Chemistry 167, 445 (1947). 14. KalCKAR, H. M., J. biol. Chemistry 167, 461 (1947). - 15. SegAx, H. L. and B. M. BRENNER, J. biol. Chemistry 235, 471 (1960). - 16. LEYBold, K., J. BeCKMANN and L. WeIsBecker, This journal 7, 25 (1969). 17. Belfield, A. and D. M. Goldberg, Clin. Chem. New York 15,931 (1969).
Dr. J.-P. Pẹrsijn Amsterdam C Sarphatistraat 106 